darzyć, a nadto $\mathrm{w}$ bardzo silnym podkreśleniu tego ostatniego jako obowiązku każdego z wiernych, widzę podstawę tej metamorfozy, którą pojęcie miłości przeszło w Nowym Testamencie i później dzięki niemu na świecie.

Lublin

KS. FELIKS GRYGLEWICZ

Ks. Jerzy Chmiel

\title{
PAWEŁ VI O ZADANIACH WSPÓLCZESNEJ EGZEGEZY BIBLIJNEJ
}

14 marca 1974 r. papież Paw eł VI wygłosił przemówienie do członków Papieskiej Komisji Biblijnej zebranych w Rzymie na sesji plenarnej ${ }^{1}$. Jak wiadomo, Papieska Komisja Biblijna została zreorganizowana na mocy motu proprio Sedula cura z dnia 27 czerwca 1971 r. ${ }^{2}$ Komisja składa się z 20 członków, na jej czele stoi - według statutu - prefekt Kongregacji dla Nauki Wiary, kard. Franciszek S e per ${ }^{3}$, a sekretarzem został mianowany przez Ojca św. biskup Albert Descamps ${ }^{4}$. Papieska Komisja Biblijna, której początki siegają pontyfikatu Leona XIII (rok powołania 1902), ma podwójne zadanie: 1) podtrzymywanie postępu nauk biblijnych w Kościele, 2) interpretację Pisma św. według jedynej pewnej linii wiernej Słowu Bożemu.

Mając na uwadze aktywną rolę Komisji Biblijnej w rozwoju nauk biblijnych, pierwsze przemówienie Ojca św. do członków tejże Komisji nosi znamiona pewnego programu, jaki został im dany do realizacji. Dlatego chcąc mówić o aktualnych zadaniach katolickiej biblistyki, będzie rzeczą rozsądną oprzeć się na tej wypowiedzi papieskiej.

1. Kontekst Kościoła pierwotnego.

„Pismo św., a w szczególności Nowy Testament, powstało w łonie społeczności Ludu Bożego, Kościoła skupionego wokół apostołów, którzy wychowani w szkole Jezusa, stawszy się świadkami Jego zmartwychwstania, przekazali czyny i naukę Mistrza, wyjaśniając zbawcze znaczenie wydarzeń, jakich byli świadkami. Jest rzeczą 1974.

1 Tekst przemówienia w j. franc. w L'Osservatore Romano, 15 marca

2 AAS 63 (1971) 665-669. Tłumaczenie polskie ks. J. Chmiela w: Ruch Bibli. i Lit. 25 (1972) 30-32.

3 Zob. Ruch Bibl. i Lit. 25 (1972) 270-272.

4 Wg L'Osservatore Romano, 22 marca 1973. 
słuszną rzec, iż jeśli słowo Boże zebrało i zrodziło Kościól, to także Kościół jest w pewien sposób rodzicielem Pisma św., w którym wyraził lub uznał, dla wszystkich przyszłych pokoleń, swoją wiarę, nadzieję i regułę życia na tym świecie".

W świetle tych słów wydaje się, iż należy pogłębić bardziej pod kątem eklezjologicznym traktaty o natchnieniu biblijnym i kanonie ksiąg świętych. Zarówno praktyka duszpasterska, jak i studia monograficzne wskazują na pewien „niedowład interpretacyjny" tychże traktatów, tak przecież ważnych $\mathrm{z}$ teologicznego punktu widzenia dla rozumienia zjawiska Biblii ${ }^{5}$. Chodzi tu o zmianę perspektywy: o fakcie inspiracji i o kryteriach kanonu nie wystarczy mówić od strony orzeczeń Magisterium Kościoła - jest to dogmatyczna niejako strona zagadnienia. Trzeba zwrócić większą uwagę na Kościół pierwotny, który jest przyczyną celową inspiracji i kanonu.

\section{Teologiczne Sitzim Leben.}

„Studia ostatnich dziesięcioleci przyczyniły się walnie do uwydatnienia ścisłego związku między Pismem a Kościołem. Podkreśliły one istotną strukturę, środowisko życiowe (Sitz im Leben), modlitwę, przylgnięcie do Pana, skupienie wokół apostołów, trudności w odniesieniu do otaczającego świata, tradycję ustną i pisaną, wysiłek misyjny i katechetyczny, jak również-pierwsze próby w zróżnicowanych sferach religijnych i kulturalnych."

Pojęcie ,środowiska życiowego (Sitz im Leben), wyrosłe na gruncie egzegezy protestanckiej (H. Gunkel), stało się ogromnie użyteczne w pracach egzegetycznych. Ale też nabrało częstokroć charakteru psychologicznego (Sitz im Leben autora czy redaktora) lub socjologicznego (Sitz im Leben grupy przed- lub popaschalnej), za mało natomiast podkreślało się kontekst witalny Kościoła - ponad wszystkimi lokalnymi gminami chrześcijańskimi. Zadaniem egzegetów będzie rozpoznawanie i opracowywanie praw teologicznego Sitz im Leben Ksiąg Swiętych tak Lưdu Bożego Nowego i jak Starego Przymierza. Prawa owe należałoby wyrazić przy pomocy współczesnego języka ${ }^{6}$.

Podkreślano też wpływ liturgii na powstawanie ksiąg biblijnych; wydaje się wszelako, że należałoby więcej zwrócić uwagę na rolę

5 Zob. J. T. Burtchae11, Catholic Theories of Biblical Inspiration since 1810. A Review and Critique, Cambridge 1969. - B. V a w ter, Biblical Inspiration, Philadelphia 1972. - Warto przypomnieć: J. H. N e wman, On the Inspiration of Scripture, oprac. J. D. Holmes i R. Murray, London-Dublin-Melbourne 1967. Zob. także pracę zbior. pod red. E. K äsemanna, Das Neue Testament als Kanon, Berlin 1973 (=Göttingen 1970).

Zob. R. La pointe, La valeur linguistique du Sitz im Leben, w: Biblica 52 (1971) 469-487. 
społeczności (Kościoła) aniżeli na same formy, które mogły się zmieniać.

3. Wyniki metody historyczno-krytycznej.

„Wydaje się, że cechą charakterystyczną współczesnej egzegezy jest refleksja nad głębokimi relacjami, jakie zachodzą pomiędzy Pismem św. a Kościołem pierwotnym. Czyż badania nad historią tradycji, form i redakcji (Traditions-Form-Redaktionsgeschichte) ... nie wchodzą w skład owej refleksji?"

W tym roku mija właśnie 10 lat od wydania instukcji Sancta Mater Ecclesia o prawdzie historycznej ewangelii, gdzie zostaia dopuszczona możliwość posługiwania się przez egzegetów katolickich metodą Formgeschichte przy pewnych korekturach metodologicznych. ${ }^{7}$ Przygotowało to pozytywny osąd o rezultatach tej metody w Konstytucji dogmatycznej Dei verbum (n. 19). Na przestrzeni 10 lat metoda historii Form (Formgeschichte) rozwinęła się w metodę historii redakcji (Redaktionsgeschichte). W tymże samym czasie metoda historyczno-krytyczna przyniosła egzegezie katolickiej wiele korzyści. Wprawdzie można spotkać się jeszcze z zarzutami, że w przyjęciu tej metody tkwi źródło kryzysu wiary w Kościele, ale jest to zarzut niesłuszny i krzywdzący. Co więcej - jesteśmy już dzisiaj przekonani, że metoda historyczno-krytyczna pomogła w przezwyciężeniu antynomii, jakie powstały między rozumieniem Biblii a mentalnością współczesnego człowieka. (Obserwujemy dzisiaj trudności w rozwiązyniu tych antynomii najjaskrawiej na przykładzie Koranu). W każdym razie metoda historyczno-krytyczna stanowi w enuncjacji papieskiej niejako punkt wyjścia dla pogłębionej refleksji teologicznej nad tekstem Pisma św.

Rzecz oczywista, że nie wolno tracić sprzed oczu ograniczoności tej metody, wynikającej $\mathrm{z}$ historycyzmu filozoficznego dominującego w czasach powstawania omawianej metody. Ale nie ma metody uniwersalnej, dlatego istnieje konieczność adaptacji nowych metod uzupełniających. ${ }^{8}$

4. Recepcja metod strukturalistycznych.

„Czy współczesne poszukiwania możliwości integracji lektury „diachronicznej", tzn. uwzględniającej rozwój historyczny tekstu, z punktem widzenia ,,synchronicznym”, czyli takim, który uwzględnia powiązania literackie i egzystencjalne każdego tekstu w odniesieniu do

7 Instructio de historica Evangeliorum veritate z 21 kwietnia 1964. Zob. AAS 56 (1964) 712-718. Tłum. polskie ks. A. Klawka w: Ruch Bibl. i Lit. 17 (1964) 200-207.

${ }_{8}$ Zob. J. Chmiel, W spółczesna egzegeza starotestamentalna a duszpasterstwo, w: Ruch Bibl. i Lit. 26 (1973) 296-307. 
całościowego układu językowego i kulturalnego - nie wdrażają się widocznie w życie Kościoła?"

Niewątpliwie Ojciec św. czyni tu przejrzystą aluzję do strukturalizmu. Jest to problem, który egzegeza musi rozwiązać. Panuje $\mathrm{w}$ tej dziedzinie wielkie zamieszanie pojęć i wiele niedopowiedzeń; jednak trzeba zgodzić się odnośnie następujących stwierdzeń: ${ }^{9}$

a) strukturalizm jako ideologia (= model) nie może być przez chrześcijaństwo przyjęty;

b) analizy strukturalistyczne jako metoda mogą być użyteczne w refleksji teologicznej.

Dla egzegety metoda synchroniczna w połaczeniu $\mathrm{z}$ diachronicznym (tzn. historycznym) ujęciem Objawienia Bożego pozwoli najpierw niejako „uwolnić" tekst biblijny z okowów historycyzmu, tzn. historycznych uwarunkowań rodzaju literackiego, stylu, mentalności autora lub redaktora. Tekst biblijny musi „przemówić” do dzisiejszego czytelnika lub słuchacza wierzącego, nie może pozostać czcigodnym pomnikiem literackim. Inna korzyść metod strukturalistycznych w biblistyce to możliwość wydobycia pełnego przekazu każdego tekstu. W tej sytuacji k a ż d y tekst mówi od siebie, nie jest uzależniony od innych rozmaitymi relacjami interliterackimi. Objawienie Boże może być niejako pełniej wydobyte z przekazów słownych.

\section{Pluralizm teologii biblijnych.}

,Traktowanie o wielości teologii lub lepiej o różnych aspektach komplementarnych, w których są przedstawiane i obrazowane rozmaite podstawowe tematy Nowego Testamentu, jak zbawienie, Kościół, osoba Chrystusa - czyż nie przypomina na nowo zgodnej symfonii żyjącej wspólnoty, która przy pomocy różnorakich głosów wyznaje wiarę w jedności misterium?"

Różnorodność i komplementarność ujęć teologicznych, tak w Starym jak i w Nowym Testamencie, świadczy o bogactwie tajemnic historii zbawienia, które poszukiwały różnych form ludzkiego wyrazu. Wielość teologii biblijnych to nie tylko sprawa odczytania tekstu przez nas (problem hermeneutyczny), ale problem formułowania wiary $\mathrm{w}$ łonie społeczności wierzących (problem redakcyjny teologiczny). Możemy zatem mówić w Starym Testamencie na przykład o teologii kapłańskiej, deuteronomistycznej, prorockiej, mądrościowej, a w Nowym - o teologii poszczególnych synoptyków, Jana czy Pawła. Ten

9 Zob. G. Schiw y, Strukturalismus und Christentum. Eine gegenseitige Herausforderung, Freiburg-Basel-Wien 1969. Tenże, Neue Aspekte des Strukturalismus, München 1971. - A. J. N c N i choll, Lo strutturalismo, Roma 1971. - $\mathrm{Cz}$. Bartnik, Możliwość stosowania analizy strukturalistycznej $w$ teologii, w: Znak nr 228 (1973) 720-738. - A. Z aborski, O recepcji metod strukturalnych $w$ biblistyce, w: Ruch Bibl. i Lit. 26 (1973) 117-130. 
wachlarz różnych perspektyw teologicznych chroni słowo Boże przed zamknięciem w jakimś jednostronnie (einseitig — jak to określał jednostronność egzegezy protestanckiej M. J. Lag range) określonym systemie pojęć, a z drugiej strony zwiększa moźliwości poznawcze Objawienia Bożego ${ }^{10}$.

6. Perspektywy nowej hermeneutyki biblijnej.

„Funkcja hermeneutyczna, która od jakiegoś dziesięciolecia jawi się obok egzegezy historyczno-literackiej - czy nie zachęca egzegety do przekroczenia etapu badań „czystego tekstu pierwotnego" i do uwzględnienia faktu że to właśnie Kościół, społeczność żyjąca, „,aktualizuje" orędzie Boże dla współczesnego człowieka?"

6.1. Obecnie hermeneutyka biblijna przestała być zbiorem reguł dla odszukania właściwego sensu biblijnego, a stała się posta wa badawcza. „Hermeneuta - pisze H. Cazelles ${ }^{11}$ - ma na uwadze, że lud, pośród którego zostały zredagowane teksty biblijne i dla którego zostały one zredagowane, jest ciągle ludem żyjącym." Egzegeza historyczno-literacka - oprócz wszystkich swoich dobrych stron - stwarza pewien dystans między tekstem powstałym niegdyś, w przeszłości, a odbiorcą (słuchaczem, czytelnikiem) współczesnym. Funkcja hermeneutyczna - jak zauważa P. Ri c o e u ${ }^{12}$ zmierza do tego, że należymy do tej samej tradycji co tekst. Ôw „łuk hermeneutyczny” - jak się to chętnie określa ${ }^{13}$ - gwarantuje ciągłość (principium continuitatis) między faktem historycznym a jego interpretacją dzisiaj, dzięki jednej i tej samej społeczności - Kościołowi, u której podstaw leżą te same fakty przez nią dzisiaj interpretowane.

6.2. Ojciec św. zwraca uwagę na konieczņość aktualizacji orędzia biblijnego: „Do was należy, egzegeci, aktualizacja, według

10 Powstało nowe ezasopismo: Bulletin de Théologie Biblique (obecnie: Biblical Theology Bulletin, skrót: BThB). Zob. szczególnie: J. H a r v e y, L'avènement de la théologie biblique diachronique de l'Ancien Testament. La décennie 1960-1970, BThB 1 (1971) 5-31. - W. J. Harrington, Théologie du Nouveau Testament, BThB 1 (1971) 173-192. - G. F. H a s e 1, Théologie de l'Ancien Testament, BThB 2 (1972) 179-200. - P. Grech, Problèmes methodologiques contemporains dans la théologie du Nouveau Testament, BThB 2 (1972) 263-282.

11 La nouvelle herméneutique biblique, Brussel 1969, 15. Zob. tegoż, Ecriture, Parole et Esprit ou trois aspects de l'herméneutique biblique, Paris 1971.

12 W zbiorze: Exégèse et herméneutique, Paris 1971, 291. Zob. także: Esegesi ed ermeneutica. Atti della XXI Settimana Biblica, Brescia 1972.

13 Zob. R. La pointe, Panorama de l'herméneutique actuelle, w: Bulletin de Théologie Biblique 2 (1972) 107-156. - J. Chmie 1, Problemy współczesnej hermeneutyki biblijnej, w: Ruch Bibl. i Lit. 25 (1972) $2-12$. 
myśli Kościoła żyjącego, Pisma świętego, aby nie pozostawało tylko pomnikiem przeszłości, lecz aby było źródłem światła, życia i działania. To stanie się wówczas, gdy wyniki egzegezy będą służyły funkcji kerygmatycznej Kościoła, dialogowi, będą otwarte na refleksje teologii systematycznej i nauczanie moralne, staną się użyteczne w pastoralnej w dzisiejszym świecie."

6.3. Paweł VI podkreślił mocno konieczność współpracy mi ęd zydy s c y plin arnej egzegezy z innymi naukami teologicznymi, przede wszystkim z teologią dogmatyczną i moralną: „Zarysowuje się konieczność „międzydyscyplinarności” (interdisciplinarité termin użyty w przemówieniu dwukrotnie) między biblistą a specjalistą teologii dogmatycznej, moralnej, prawnikiem, pastoralista, misjologiem." Tak więc ośrodkiem jednoczącym nowej syntezy teologicznej naszych czasów ma się stać już nie jakiś system filozoficzny - jak w średniowieczu - ale Pismo święte anima Sacrae Theologiae ${ }^{14}$.

7. Zadanie ekumeniczne i misyjne.

„Biblista jest wezwany do oddania usługi podobnej do zadania ekumenicznego i misyjnego w Kościele."

Lektura Pisma św. in medio Ecclesiae powinna stać się również lekturą ad extra Ecclesiae. Zadania owe mają także charakter świadectwa o obecności Boga w Piśmie świętym: „Prawdziwe otwarcie egzystencjalne na tajemnicę Boga Miłości, bez czego nasza egzegeza, jakkolwiek by nie była uczona, pozostaje z konieczności zaciemniona, może mieć w nas miejsce z pomocą światła łaski Bożej, o którą trzeba zawsze pokornie prosić."

Egzegeci katoliccy oczekując ze strony Kościoła ciągle otuchy i zachęty - o czym mówi Konstytucja Dei verbum (n. 23), z ufnością patrzą na możliwości wspólnego wysiłku, pod opieką Magisterium Kościoła, w badaniach przeprowadzanych nad świętymi tekstami. Historia, aczkolwiek surowo ocenia wszelkie niedociągnięcia $w$ tej dziedzinie, dostarcza pokrzepiających argumentów. Ojciec św. posłużył się przykładem egzegezy wielkiego mistrza, jakim był o. Marie Joseph L a grange, OP (1855-1938). A oto inny argument, jaki wysuną w 1947 r. inny z najwybitniejszych biblistów naszego stulecia, protestant, William Foxwell A l b right (1891-1971), kiedy mówił o napięciu, jakie wytworzyło się $\mathrm{w}$ początkach XX wieku w związku z odpowiedziami ówczesnej Papieskiej Komisji Biblijnej odnośnie badań krytycznych Starego Testamentu: „Osobiście, jako protestant 
z przekonania, sądzę, że reakcja była za gwałtowna i odpowiedzi za zbyt sztywne. Lecz położyly kres wypaczeniom krytyki literackiej i historycznej, które z obozu protestanckiego przenosiły się gwałtownie do katolickiego. A wynik jest taki, że badania katolickie nad Starym Testamentem są wolne od wplywu niedorzeczności charakterystycznych dla badań protestanckich ostatnich pięćdziesięciu lat." ${ }^{15}$

Kraków

KS. JERZY CHMIEL

\section{Ks. Stanisław Nowak}

\section{MODLITWA RÓŻAÑCOWA W ADHORTACJI PAWKA VI „MARIALIS CULTUS"}

Papieże naszych czasów chętnie zabierają głos na temat różańca. Ojciec Swięty Pa weł VI czyni to w encyklice Christi Matri (1966), w adhortacji Recurrens mensis October (1969), a ostatnio w adhortacji Marialis cultus. Adhortacja apostolska Marialis cultus z 2 lutego 1974 r. poświęca ożywieniu i pogłębieniu tej zakorzenionej praktyce pobożności maryjnej znaczne partie trzeciej swej części. Znaczenie tej wypowiedzi jest doniosłe $\mathrm{z}$ uwagi na powagę dokumentu. Należy go bezwątpienia umieścić, wraz z adhortacją Signum magnum z 13 maja 1967 r. w kontekście VIII rozdziału konstytucji soborowej Lumen Gentium i uważać za jej przedłużenie pastoralne. Poza tym myśli Ojca Swiętego na temat różańca zawarte w tej adhortacji nie pozbawione oryginalności, którą zauważają teologowie rozmaitych orientacji ${ }^{1}$. Warto więc na nie zwrócić baczniejszą uwagę.

\section{Różaniec - modlitwą ewangeliczną}

Adhortacja wskazuje przede wszystkim na związek modlitwy różańcowej z Pismem Świętym. Za Pi u s e m XII nazwany jest różaniec „,skrótem całej Ewangelii"." Określa się go jako „,psałterz Dziewicy”, „modlitwę ewangeliczną", mówi się o jego ewangelicznej naturze. Formuły przecież tej modlitw'y - uczy papież - zaczerpnięte są wprost z Ewangelii, rozpamiętują one pierwszą tajemnice naszej wiary: Wcielenie Słowa Bożego. Także i tajemnice różańcowe mają swe źródło w Ewangelii, wyciągają z niej centralne treści: Wcielenie, Odkupienie,

15 Cyt. za L. Alonso Schökel, L’uomo d'oggi di fronte alla Biblia, Brescia 1963, 34.

1 Por. La vie spirituelle, nr 602 (1974), str. $446 \mathrm{n}$.

2 Epistula Philippinas Insulas ad Archiepiscopum Manilensem, AAS 38 (1946), str. 419. 